\title{
Iridoids, Flavonoids, and Antioxidant Capacity of Cornus mas, C. officinalis, and C. mas $\times$ C. officinalis Fruits
}

\author{
Svitlana Klymenko ${ }^{1}$, Alicja Zofia Kucharska ${ }^{2} \odot$, Anna Sokót-Łętowska ${ }^{2} \odot$, Narcyz Piórecki ${ }^{3,4}$, \\ Dominika Przybylska ${ }^{2, *(\mathbb{D})}$ and Olga Grygorieva ${ }^{1}$ (D) \\ 1 Department of Fruit Plants Acclimatisation, M.M. Gryshko National Botanical Gardens of Ukraine National \\ Academy of Sciences, 01014 Kyiv, Ukraine; cornusklymenko@gmail.com (S.K.); \\ olgrygorieva@gmail.com (O.G.) \\ 2 Department of Fruit, Vegetable and Plant Nutraceutical Technology, Wrocław University of Environmental \\ and Life Sciences, 51-630 Wrocław, Poland; alicja.kucharska@upwr.edu.pl (A.Z.K.); \\ anna.sokol-letowska@upwr.edu.pl (A.S.-Ł.) \\ 3 Arboretum and Institute of Physiography in Bolestraszyce, 37-722 Przemyśl, Poland; narcyz360@gmail.com \\ 4 Institute of Physical Culture Sciences, Medical College, University of Rzeszów, 35-959 Rzeszów, Poland \\ * Correspondence: dominika.przybylska@upwr.edu.pl
}

check for updates

Citation: Klymenko, S.; Kucharska, A.Z.; Sokół-Łętowska, A.; Piórecki, N.; Przybylska, D.; Grygorieva, O.

Iridoids, Flavonoids, and Antioxidant Capacity of Cornus mas, C. officinalis, and C. mas $\times$ C. officinalis Fruits. Biomolecules 2021, 11, 776. https:// doi.org/10.3390/biom11060776

Academic Editors: Vito Verardo and Christophe Hano

Received: 26 April 2021

Accepted: 17 May 2021

Published: 21 May 2021

Publisher's Note: MDPI stays neutral with regard to jurisdictional claims in published maps and institutional affiliations.

Copyright: (C) 2021 by the authors. Licensee MDPI, Basel, Switzerland. This article is an open access article distributed under the terms and conditions of the Creative Commons Attribution (CC BY) license (https:/ / creativecommons.org/licenses/by/ $4.0 /)$.

\begin{abstract}
The fruits of Cornus mas and Cornus officinalis have been known and appreciated in folk medicine for years and have a high biological value, which is mainly connected with their polyphenols and iridoids content. However, hybrids of $C$. mas $\times$ C. officinalis have not been investigated. The aim of this study was to evaluate the iridoids, anthocyanins, and flavonols content, and antioxidant capacity of Cornus mas, Cornus officinalis, and C. mas $\times$ C. officinalis. Iridoids and flavonoids were quantified by the High-Performance Liquid Chromatography (HPLC) method. Antioxidant capacity (AC) was measured using 2,2-diphenyl-1-picrylhydrazyl ( $\mathrm{DPPH}^{\bullet}$ ), 2,2'-azino-bis (3-ethyl benzothiazoline-6-sulfonic acid $\left(\mathrm{ABTS}^{\bullet+}\right.$ ), and ferric reducing antioxidant power (FRAP) tests. Total phenolic content (TPC) was evaluated using the Folin-Ciocalteu reagent. Among the C. mas cultivars and C. officinalis genotypes, there was considerable variation in the content of iridoids, flavonoids, and AC. Interspecific hybrids C. mas $\times$ C. officinalis contained more iridoids than C. mas and more anthocyanins than C. officinalis and additionally had higher AC and TPC than C. officinalis and most C. mas. AC, TPC, and the presence of iridoids, anthocyanins, and flavonols in hybrids C. mas $\times$ C. officinalis are reported for the first time. The Cornus species deserve special attention due to their highly biologically active substances, as well as useful medicinal properties.
\end{abstract}

Keywords: Cornus mas; C. officinalis; C. mas $\times$ C. officinalis; iridoids; flavonoids; antioxidant capacity

\section{Introduction}

Cornus mas L. (cornelian cherry) has been known in garden cultivation for 4000 years. This species originates from the Caucasus and from there it spread through Turkey, Romania, Bulgaria, and further on European continent [1,2]. A very rich composition of biologically active compounds found in the fruits of Cornus mas [3-10], which have a wide range of pharmacological action, such as antibacterial $[7,11,12]$, hypolipidemic [7], antioxidant [6,13], anticoagulant [14], antiparasitic [15], cardioprotective [16], anticancer [17], hepatoprotective [18], and anti-inflammatory [19], and according to [20], could constrain the incidence of long-term complications of diabetes mellitus. Biologically active compounds are not only in fruits, but also in flowers, leaves, bones, and bark. The use in folk medicine of these parts of the C. mas plant has been known and appreciated for many years, especially in Asia [4,8,21-29]. Recent studies have proven that C. mas stones are a good source of various bioactive hydrolyzable tannins and show high antioxidant activity [30], while C. mas leaf extract contains a hydroxycinnamic acid derivatives, flavonols, ellagitannins, as well as iridoids, and shows high antibacterial activity against Gram-negative 
bacteria [31]. Moreover, latest research embraced evaluation of the unripe fruits towards the detection and isolation of biosynthetic precursors of compounds found in mature fruits [32].

Another one is no less known as a medicinal plant Cornus officinalis Torr. ex Dur. (Japanese cornel), which is well distributed in the Tianmu Mountain, Funiu Mountain, and Qinling-Bashan Mountain in China [33] as well as Korea and Japan [34], is virtually unknown in Europe and grows only in the collections of Botanical Gardens. It is cultivated in large areas in Japan, the local name being sandzaki. In China, C. officinalis is used as traditional Chinese medicine [34,35]. The fruit of $C$. officinalis is a primary medicine that was first recorded in Shen Nong's Materia Medica about 2000 years ago [34] but was included in the Chinese Pharmacopoeia in 1963. More than 20 prescriptions containing C. officinalis have been used to treat various hepatic and renal diseases in China [36].

Modern pharmacological studies have shown that $C$. officinalis exhibits a broad range of pharmacological activities against diseases, such as diabetes [34,37-39], and has cardioprotective [40], antioxidative [41,42], anti-inflammatory, antiaging [40], neuroprotective [40,43], antibacterial [40], anti-allergic [42], and antidepressant [44] effects.

About 300 chemical compounds, such as alkaloids, iridoids, flavonoids, polysaccharides, organic acid, terpenoids, essential oils, and other compounds, have been isolated and identified from $C$. officinalis fruits [45-51]. The main active iridoids of $C$ officinalis are morroniside and loganin. These compounds have similar hypoglycemic, nephroprotective, and neuroprotective activity. In addition, morroniside exhibits myocardial protection and antioxidant capacity [50]. Biologically active compounds are present not only in fruits but also in different parts of the plant: leaves [2,52,53], seeds [54-56], and twigs [2,56]. As far as C. officinalis is concerned, most research is devoted to pharmacological, often biochemical properties of fruit and vegetative organs, and limited data exist on breeding and culture. There are some cultivars created in Japan. For the collection of raw materials of C. officinalis, plantings from genotypes selected from seedlings of wild and cultivated samples are used.

There are virtually no reports about $C$. mas and C. officinalis crossbreeding. Information concerning their cultivation abroad is rather scant. However, Polish authors [57] described the crossbreeding hybrid from Germany, investigated its origin at the molecular level, and showed its hybridogenic origin.

In Ukraine, there are widespread cultivars of Cornus mas with large fruits but with lower content of some biologically active compounds. In Asia, Cornus officinalis is widely distributed. It has smaller fruits but high content of biologically active compounds. Probably, it is possible to select genotypes with larger fruits and much higher content of biologically active compounds by inter-hybridization of genotypes, which was the purpose of this study. According to our knowledge, this is the first detailed paper about iridoids and flavonoids content and antioxidant capacity of $C$. mas $\times$ C. officinalis hybrids. These novel hybrids could combine the beneficial features of both C. mas and C. officinalis, thus improving the composition of bioactive compounds and reducing the shortcoming of smaller C. officinalis fruits. In this study, Cornus mas and Cornus officinalis were used for comparison in order to provide thorough and comprehensive results.

\section{Materials and Methods}

\subsection{Chemicals and Reagents}

Loganic acid (LA), loganin (L) quercetin 3-O-glucoside (Q-glc), kaempferol 3-Oglucoside (Kf-glc), and cyanidin 3-O-glucoside (Cy-glc) were purchased from Extrasynthese (Genay, France). Further, 2,2-diphenyl-1-picrylhydrazyl (DPPH ${ }^{\bullet}$ ) ferrous chloride, tripyridyltriazine (TPTZ), potassium persulfate, 2,2'-azino-bis(3-ethylbenzthiazoline-6sulphonic acid) (ABTS ${ }^{\bullet+}$ ), 6-hydroxy-2,5,7,8-tetramethylchroman-2-carboxylic acid (Trolox), and gallic acid were obtained from Sigma Chemical Co. (Steinheim, Germany). Methanol, acetonitrile, formic acid, and hydrochloric acid were obtained from POCh (Gliwice, Poland). All chemicals and solvents were of analytical grade. 


\subsection{Biological Material}

The fruits of five cultivars of Cornus mas (Ekzotychnyi, Koralovyi Marka, Koralovyi, Uholok (black fruit), and Yantarnyi (yellow fruit)), two genotypes C. officinalis (Co-01 and $\mathrm{Co}-02)$, and two interspecific hybrids C. mas $\times$ C. officinalis ( $\mathrm{CmCo}-01$ and $\mathrm{CmCo}-02)$ collected and selection in M.M. Gryshko National Botanical Garden of NAS of Ukraine (NBG) were the objects of these investigations. Plants $\mathrm{CmCo}-01$ and $\mathrm{CmCo}-02$ are artificial hybrids from crossing C. officinalis $\times$ C. mas [58]. The raw material was collected in the period of full ripeness (September 2015). The fruits of cultivars of C. mas and C. officinalis and C. mas $\times$ C. officinalis are shown in Figure 1. Approximately $500 \mathrm{~g}$ of fruits from 3 trees of each cultivar (approximately, 150-200 $\mathrm{g}$ of fruits per tree) were harvested and immediately frozen at $-20^{\circ} \mathrm{C}$.

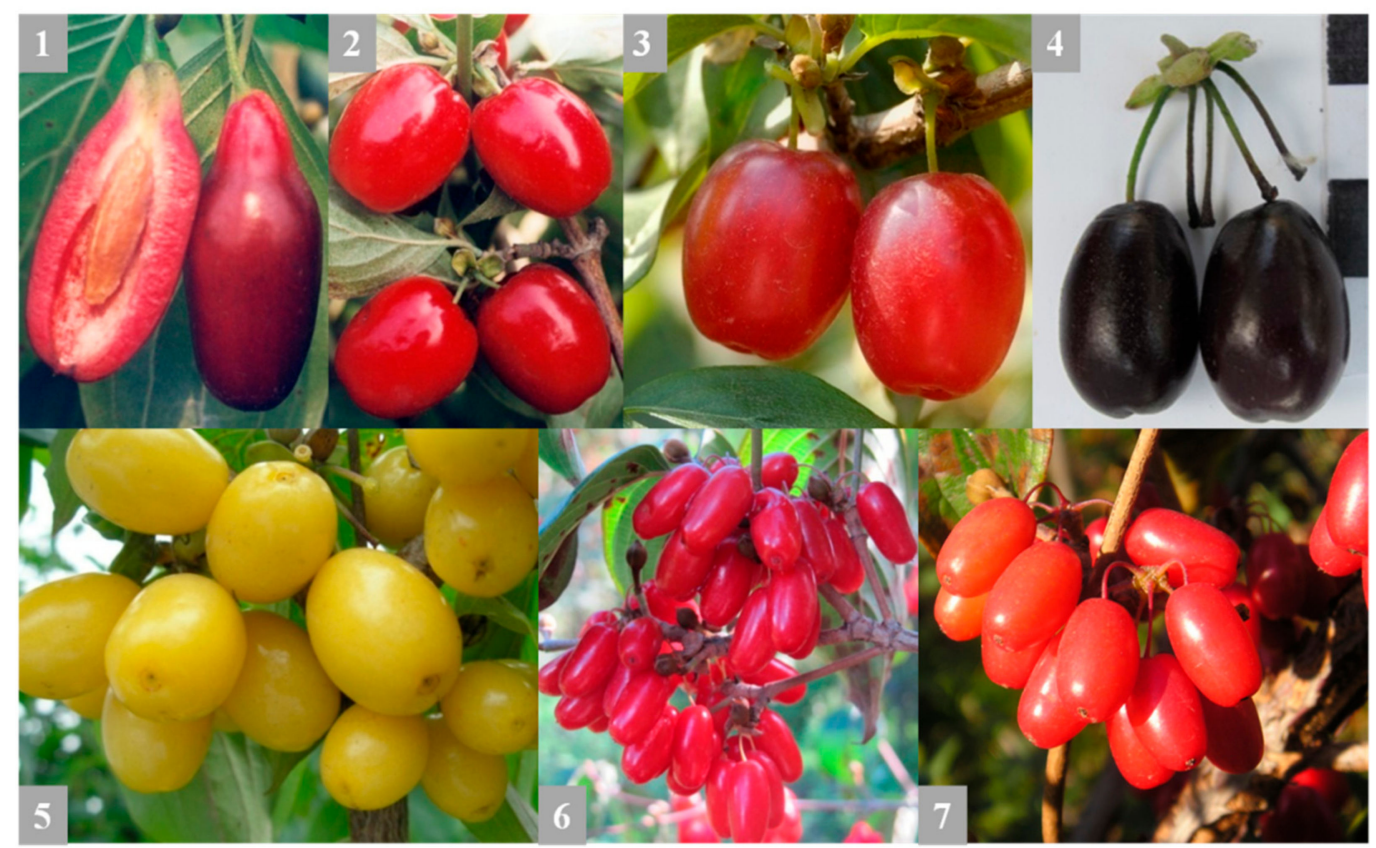

Figure 1. Fruits of different cultivars of Cornus mas L. (1-Ekzotychnyi; 2-Koralovyi Marka; 3-Koralovyi; 4-Uholok; 5-Yantarnyi), C. officinalis Siebold \& Zucc. (6) and C. mas $\times$ C. officinalis (7) of a selection of M.M. Gryshko National Botanical Garden (Kyiv, Ukraine).

\subsection{Preparation of Extracts for Analysis of Active Compounds and Antioxidant Capacity}

Before analysis, the stones were manually removed, and the fruits without stones (300-350 g) were homogenized. The amount of about $5 \mathrm{~g}$ of homogenized fruits (combined from three trees for each cultivar) was extracted with $80 \%$ aqueous methanol $(v / v)$ acidified with $1 \% \mathrm{HCl}$ to a final volume of $50 \mathrm{~mL}$ at room temperature. The extraction was performed in an ultrasonic bath (Polsonic, Warsaw, Poland) for $15 \mathrm{~min}$. All extracts were filtered through pickling mixture paper filters (Whatman filter No. 1, Cytiva, Marlborough, MA, USA), and then they were subjected to analyses.

\subsection{HPLC Quantification of Iridoids and Flavonoids}

The High-Performance Liquid Chromatography equipped with Photodiode Array detector (HPLC-PDA) method was described previously [59]. The quantification analysis was performed using a Dionex (Germering, Germany) system, equipped with the diode array detector model Ultimate 3000, quaternary pump LPG-3400A, autosampler EWPS-3000SI, and thermostated column compartment TCC-3000SD, and controlled by Chromeleon v. 6.8 software. The Atlantis T3 $(250 \mathrm{~mm} \times 4.6 \mathrm{~mm}$ i.d., $5 \mu \mathrm{m})$ column (Waters, Dublin, Ireland) and the Atlantis T3 $(20 \mathrm{~mm} \times 4.6 \mathrm{~mm}$ i.d., $5 \mu \mathrm{m})$ guard column (Waters, Dublin, Ireland) were used. The mobile phase was composed of solvent A (4.5\% formic 
acid, $v / v$ ) and solvent $B$ (acetonitrile). The elution system was as follows: $0-1 \mathrm{~min} 5 \% \mathrm{~B}$, 1-37 $\min 5-25 \%$ B, 37-42 min 25-100\% B, 42-47 min 100\% B, 47-50 min 100-5\% B, and $50-55 \mathrm{~min} 5 \%$ B. Iridoids were detected at $245 \mathrm{~nm}$, flavonols at $360 \mathrm{~nm}$, and anthocyanins at $520 \mathrm{~nm}$. Calibration curves at concentrations ranging from 0.02 to $0.3 \mathrm{mg} / \mathrm{mL}\left(\mathrm{r}^{2} \geq 0.9998\right)$ were made for five standards. Iridoids were expressed as loganic acid or loganin, quercetin 3-O-glucuronide as quercetin 3-O-glucoside, kaempferol 3-O-galactoside as kaempferol 3-O-glucoside, and anthocyanins as cyanidin 3-O-glucoside. All determination were done in triplicate. The results were expressed as milligram per $100 \mathrm{~g}$ fresh weight (FW).

\subsection{Determination of Total Phenolic Content (TPC) and Antioxidative Capacity (AC) 2.5.1. Total Phenolic Content}

Total phenolic content (TPC) of fruits was determined using the Folin-Ciocalteu reagent method according to Yen et al. [60]. Plant extracts $(0.1 \mathrm{~mL})$ were mixed with $0.2 \mathrm{~mL}$ of Folin-Ciocalteu reagent and $2 \mathrm{~mL}$ of $\mathrm{H}_{2} \mathrm{O}$, and after $3 \mathrm{~min}, 1 \mathrm{~mL}$ of $20 \%$ sodium carbonate was also added. Total polyphenols were determined after $1 \mathrm{~h}$ of incubation at room temperature in the dark. The absorbance of the resulting blue color was measured at $765 \mathrm{~nm}$. The standard curve was prepared using different concentrations of gallic acid. The results were calculated as milligram of gallic acid equivalent (GAE) per $100 \mathrm{~g}$.

\subsubsection{FRAP Assay}

Ferric reducing antioxidant power (FRAP) was measured according to Re et al. [61]. An aliquot $(1.0 \mathrm{~mL})$ of the diluted extract was added to $3 \mathrm{~mL}$ of FRAP solution (acetate buffer $(300 \mu \mathrm{M}, \mathrm{pH} 3.6)$, a solution of $10 \mu \mathrm{M}$ TPTZ in $40 \mu \mathrm{M} \mathrm{HCl}$, and $20 \mu \mathrm{M} \mathrm{FeCl}_{3}$ at 10:1:1 $(v / v / v)$ ratio). The mixture was shaken and left at room temperature for $10 \mathrm{~min}$. The absorbance was read at $593 \mathrm{~nm}$ after $10 \mathrm{~min}$.

\subsubsection{DPPH Assay}

The 2,2-diphenyl-1-picrylhydrazyl free radical (DPPH${ }^{\bullet}$ ) scavenging capacity of fruit extracts was measured by bleaching out of the purple color of 2,2-diphenyl-1-picrylhydrazyl as described by Klymenko et al. [62]. Exactly, $0.5 \mathrm{~mL}$ of solution of different concentrations of the extract was added to $2 \mathrm{~mL}$ of DPPH ethanolic solution. The mixture was shaken and left at room temperature for $10 \mathrm{~min}$. The absorbance was measured at $517 \mathrm{~nm}$.

\subsubsection{ABTS Assay}

The 2,2' -azino-bis (3-ethyl benzothiazoline-6-sulfonic acid (ABTS ${ }^{\bullet+}$ ) assay was based on the method of Du et al. [63]. Briefly, the ABTS radical cation is generated by reacting $7 \mathrm{mM}$ ABTS and $2.45 \mathrm{mM}$ potassium persulfate via incubation at room temperature $\left(23^{\circ} \mathrm{C}\right)$ in the dark for $12-16 \mathrm{~h}$. The $\mathrm{ABTS}^{\bullet+}$ solution was diluted with an absorbance of $0.700 \pm 0.040$ at $734 \mathrm{~nm}$. After the addition of $3.0 \mathrm{~mL}$ of diluted ABTS ${ }^{\bullet+}$ solution to $30 \mu \mathrm{L}$ of plant extracts, the absorbance reading was taken exactly $6 \mathrm{~min}$ after the initial mixing.

All UV-VIS measurements were recorded on a Shimadzu UV-2401PC spectrophotometer (Kyoto, Japan). All the determinations were performed in triplicate. Results of antioxidant capacity were expressed in micromole Trolox equivalent (TE) per $1 \mathrm{~g}$ FW. Calibration curves, in the range of $0.01-5.00 \mu \mathrm{mol}$ Trolox $\mathrm{L}^{-1}$, were used for the quantification of the three methods of antioxidant activity, showing good linearity $\left(r^{2} \geq 0.998\right)$.

\subsection{Statistical Analysis}

Significant differences $(p \leq 0.05)$ between means were evaluated by ANOVA and the Tukey-Kramer test. Correlation coefficients were calculated using Statistica version 13.0 software (StatSoft, Tulsa, OK, USA).

\section{Results and Discussion}

In the last few years in gardening in Ukraine, Poland, as well as other countries, new fruit and berry plants, until recently encountered only in nature, have been introduced, 
which differ by their high maintenance of valuable biologically active substances and have important economic value. Works on the introduction and selection of new species for culture in Ukraine have been conducted in the Department of Fruit Plants Acclimatisation in NBG (Kyiv, Ukraine) for over 50 years. These species of plants include Amelanchier spp., Asimina triloba (L.) Dunal, Castanea sativa Mill., Chaenomeles japonica (Thunb.) Lindl. Ex Spach, Diospyros virginiana L., Elaeagnus spp., Mespilus germanica L., Pseudocydonia sinensis Schneid., Sambucus nigra L., Shepherdia spp., and Ziziphus jujuba Mill. [2]. Much research work is being done with C. mas and C. officinalis as food and medicinal plants [21,64].

\subsection{Iridoids, Anthocyanins, and Flavonols of the Cornus Fruit Extracts}

In the present study, iridoids, anthocyanins, and flavonols content was evaluated in 5 cultivars of $C$. mas fruits, 2 genotypes of $C$. officinalis fruits, and 2 interspecific hybrids C. mas $\times$ C. officinalis fruits (Table 1). Chromatograms of iridoids and anthocyanins of Cornus mas L., C. officinalis Siebold \& Zucc., and C. mas $\times$ C. officinalis fruit extracts are shown in Figures 2 and 3. The dominant group in these fruits was iridoids, followed by flavonoids including anthocyanins and flavonols.

The total iridoids content in fruits covered a wide range from $89.09 \mathrm{mg} / 100 \mathrm{~g}$ fresh weight (FW) (C. mas cv. Ekzotychnyi) to $1441.22 \mathrm{mg} / 100 \mathrm{~g}$ FW (C. officinalis, Co-01). The average iridoids contents in the analyzed C. mas, C. officinalis, and C. mas $\times$ C. officinalis fruits were 190.11, 1117.01, and $293.47 \mathrm{mg} / 100 \mathrm{~g}$ FW, respectively. They depended significantly both on the species and the cultivar/genotype/hybrid. C. officinalis fruits contained the highest amount of iridoids-almost 6 times more than C. mas. The iridoids in the cultivars/ecotypes of $C$. mas fresh fruits were described in a previous work [5]. The total content of the two iridoids in 26 varieties and 2 ecotypes ranged from 89.91 to $493.69 \mathrm{mg} / 100 \mathrm{~g}$ FW. In the case of C. officinalis, the content of iridoids is most often given for dried ripe fruit (Fructus Corni). Liu et al. [64] reported the total content of four main iridoids in Fructus Corni in the range of 1002-3819 mg/100 g. In our research, on average, hybrids contained 1.5 times more iridoids than C. mas fruit, but almost 4 times less than $C$. officinalis fruit. This is the first report to determine the iridoid content of $C$. mas $\times$ C. officinalis fruit.
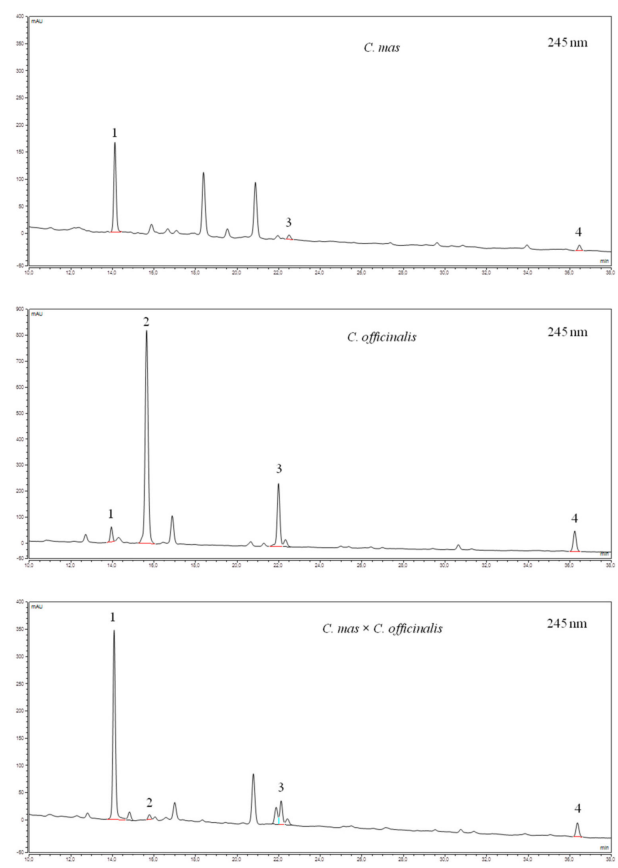

Figure 2. HPLC-PDA chromatograms $(245 \mathrm{~nm})$ of iridoids of Cornus mas L. (cv. Uholok), C. officinalis Siebold \& Zucc., and C. mas $\times$ C. officinalis fruit extracts: 1-loganic acid; 2-morroniside; 3-sweroside + loganin; 4-cornuside. HPLC-PDA, High-Performance Liquid Chromatography equipped with Photodiode Array detector. 
Table 1. Iridoids, anthocyanins, and flavonols content (mg/100 g FW) in Cornus mas L., C. officinalis Siebold \& Zucc., and C. mas $\times$ C. officinalis fruits.

\begin{tabular}{|c|c|c|c|c|c|c|c|c|c|}
\hline \multirow{2}{*}{ Compound $^{1}$} & \multicolumn{5}{|c|}{ C. mas } & \multicolumn{2}{|c|}{ C. officinalis } & \multicolumn{2}{|c|}{ C. mas $\times$ C. officinalis } \\
\hline & Ekzotychnyi & Koralovyi Marka & Koralovyi & Uholok & Yantarnyi & Co-01 & Co-02 & CmCo-01 & $\mathrm{CmCo}-02$ \\
\hline \multicolumn{10}{|c|}{ Iridoids } \\
\hline LA & $77.23 \pm 0.83 \mathrm{e}^{2}$ & $156.31 \pm 27.45 \mathrm{~d}$ & $192.71 \pm 15.00 \mathrm{c}$ & $239.02 \pm 1.79 \mathrm{~b}$ & $200.72 \pm 0.34 \mathrm{c}$ & $70.76 \pm 6.32 \mathrm{e}, \mathrm{f}$ & $46.15 \pm 3.14 \mathrm{f}$ & $269.32 \pm 3.68 \mathrm{a}$ & $193.64 \pm 16.16 \mathrm{c}$ \\
\hline Mo & nd $^{3}$ & nd & nd & nd & nd & $1037.74 \pm 87.52 \mathrm{a}$ & $529.52 \pm 30.02 b$ & $9.68 \pm 0.32 c$ & nd \\
\hline $\mathrm{S}+\mathrm{L}$ & $2.50 \pm 0.37 \mathrm{~d}$ & nd & nd & $2.84 \pm 0.25 \mathrm{~d}$ & $6.44 \pm 0.66 \mathrm{~d}$ & $223.55 \pm 18.11 \mathrm{a}$ & $172.16 \pm 10.88 \mathrm{~b}$ & $38.14 \pm 0.72 c$ & $28.27 \pm 1.72 \mathrm{c}$ \\
\hline Co & $9.36 \pm 0.56 \mathrm{e}$ & $8.81 \pm 1.37 \mathrm{e}$ & $9.04 \pm 0.92 \mathrm{e}$ & $27.07 \pm 0.86 c$ & $18.51 \pm 0.13 \mathrm{~d}$ & $109.17 \pm 9.32 \mathrm{a}$ & $44.98 \pm 3.49 \mathrm{~b}$ & $32.51 \pm 0.27 c$ & $15.38 \pm 2.11 \mathrm{~d}, \mathrm{e}$ \\
\hline Total & 89.09 e & $165.12 \mathrm{~d}, \mathrm{e}$ & $201.75 \mathrm{~d}$ & $268.93 \mathrm{c}, \mathrm{d}$ & $225.67 \mathrm{~d}$ & $1441.22 \mathrm{a}$ & $792.81 \mathrm{~b}$ & 349.65 c & $237.29 \mathrm{~d}$ \\
\hline \multicolumn{10}{|c|}{ Anthocyanins } \\
\hline Df-gal & $0.39 \pm 0.02 \mathrm{~b}$ & $0,26 \pm 0.04 b$ & nd & $32.81 \pm 0.58 \mathrm{a}$ & nd & nd & $\operatorname{tr}^{4}$ & $\operatorname{tr}$ & $0.69 \pm 0.14 b$ \\
\hline Cy-gal & $41.04 \pm 0.14 \mathrm{~b}$ & $6.83 \pm 1.18 c$ & $0.24 \pm 0.02 c$ & $216.28 \pm 8.52 \mathrm{a}$ & nd & $0.58 \pm 0.03 c$ & $1.20 \pm 0.14 c$ & $3.43 \pm 0.13 c$ & $1.75 \pm 0.21 \mathrm{c}$ \\
\hline Cy-rob & $7.62 \pm 0.02 b$ & $1.08 \pm 0.09 \mathrm{c}, \mathrm{d}$ & nd & $30.00 \pm 1.83 \mathrm{a}$ & nd & $0.28 \pm 0.04 \mathrm{c}, \mathrm{d}$ & $0.35 \pm 0.03 \mathrm{c}, \mathrm{d}$ & $1.69 \pm 0.02 c$ & $1.08 \pm 0.13 \mathrm{c}, \mathrm{d}$ \\
\hline Pg-gal & $23.59 \pm 0.12 c$ & $23.12 \pm 3.18 c$ & $3.82 \pm 0.35 \mathrm{e}$ & $138.79 \pm 3.16 \mathrm{a}$ & nd & $11.99 \pm 1.20 \mathrm{~d}$ & $6.59 \pm 0.60 \mathrm{e}$ & $58.78 \pm 1.53 b$ & $20.79 \pm 3.27 c$ \\
\hline Pg-rob & $1.86 \pm 0.00 \mathrm{~d}$ & $1.76 \pm 0.17 \mathrm{~d}$ & nd & $9.87 \pm 0.51 \mathrm{~b}$ & nd & $4.33 \pm 0.43 c$ & $2.38 \pm 0.12 \mathrm{~d}$ & $20.74 \pm 0.66 \mathrm{a}$ & $11.24 \pm 1.66 \mathrm{~b}$ \\
\hline Total & $74.50 \mathrm{~b}$ & $33.05 \mathrm{c}$ & $4.06 \mathrm{~d}$ & $427.75 \mathrm{a}$ & nd & $17.18 \mathrm{~d}$ & $10.52 \mathrm{~d}$ & $84.64 \mathrm{~b}$ & $35.55 \mathrm{c}$ \\
\hline \multicolumn{10}{|c|}{ Flavonols } \\
\hline Q-glcr & $0.22 \pm 0.01 \mathrm{~d}$ & $0.48 \pm 0.07 \mathrm{~d}$ & $0.40 \pm 0.02 \mathrm{~d}$ & $1.85 \pm 0.04 \mathrm{c}$ & $1.90 \pm 0.07 c$ & $10.83 \pm 1.28 \mathrm{a}$ & $7.89 \pm 0.72 b$ & $2.39 \pm 0.20 c$ & $0.59 \pm 0.05 \mathrm{~d}$ \\
\hline Kf-gal & $1.06 \pm 0.04 c$ & $0.48 \pm 0.08 \mathrm{~d}$ & $0.07 \pm 0.01 \mathrm{e}, \mathrm{f}$ & $8.82 \pm 0.17 \mathrm{a}$ & nd & $1.74 \pm 0.13 b$ & $0.24 \pm 0.03 \mathrm{e}$ & $1.23 \pm 0.01 \mathrm{c}$ & $0.22 \pm 0.04 \mathrm{e}$ \\
\hline
\end{tabular}

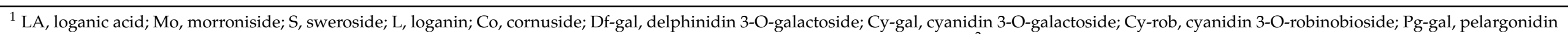

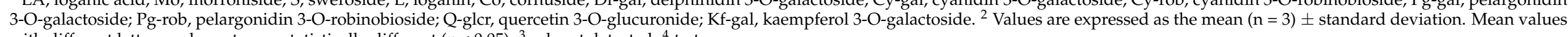
with different letters: a, b, c, etc. are statistically different $(p<0.05) .{ }^{3}$ nd, not detected. ${ }^{4}$ tr, traces. 

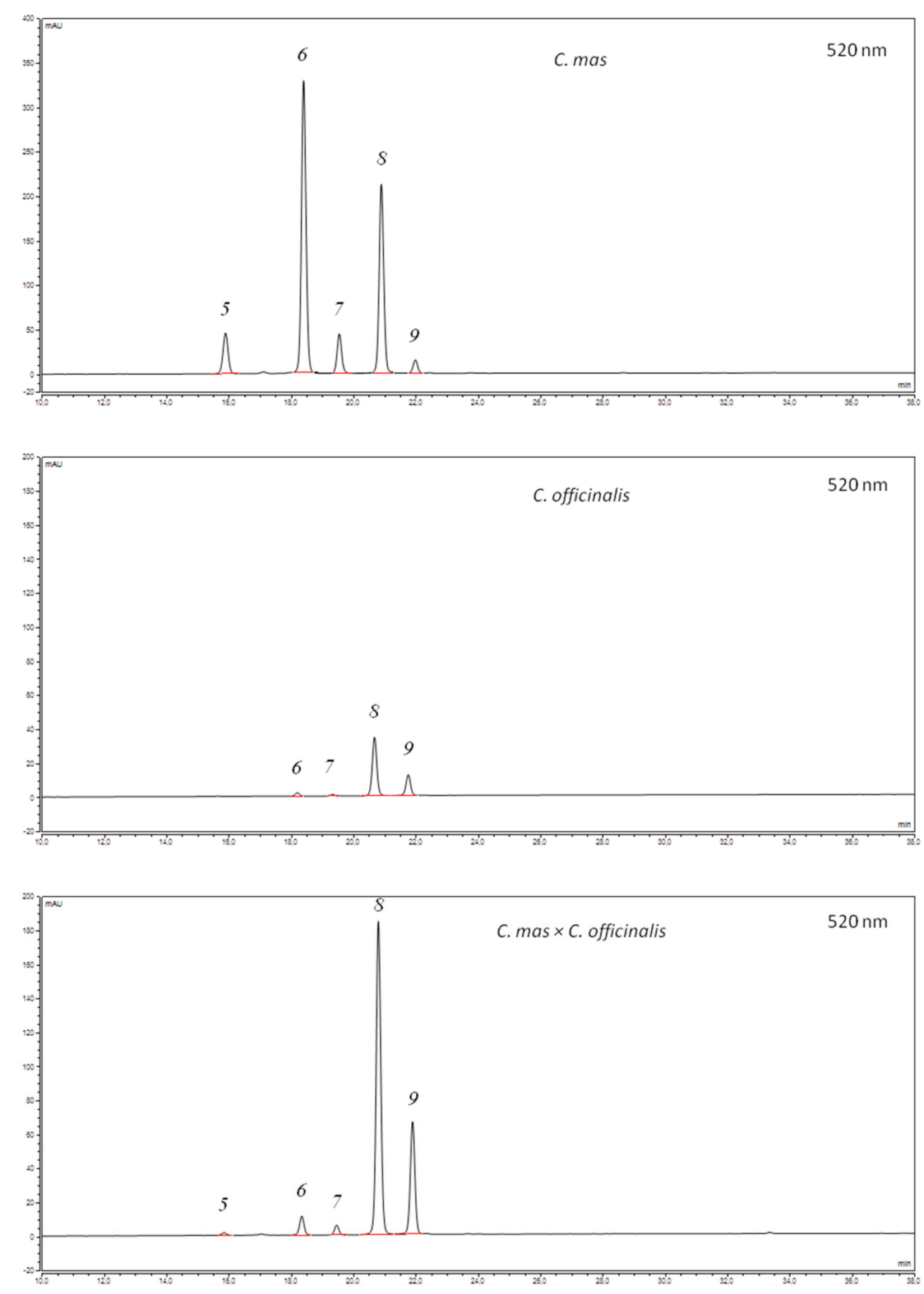

Figure 3. HPLC-PDA chromatograms $(520 \mathrm{~nm})$ of anthocyanins of Cornus mas L. (cv. Uholok), C. officinalis Siebold \& Zucc., and C. mas $\times$ C. officinalis fruit extracts: 5-delphinidin 3-O-galactoside; 6-cyanidin 3-O-galactoside; 7-cyanidin 3-O-robinobioside; 8-pelargonidin 3-O-galactoside; 9 pelargonidin 3-O-robinobioside.

In 5 cultivars of C. mas fruit, we identified loganic acid (from $77.23 \mathrm{mg} / 100 \mathrm{~g}$ FW for Ekzotychnyi to $239.02 \mathrm{mg} / 100 \mathrm{~g}$ FW for Uholok) and cornuside (from $8.81 \mathrm{mg} / 100 \mathrm{~g}$ FW for Koralovyi Marka to $27.07 \mathrm{mg} / 100 \mathrm{~g}$ FW for Uholok) and, additionally, the sum of sweroside and loganin (from $2.50 \mathrm{mg} / 100 \mathrm{~g} \mathrm{FW}$ for Ekzotychnyi to $6.44 \mathrm{mg} / 100 \mathrm{~g}$ FW for Yantarnyi), but only in three cultivars (Ekzotychnyi, Uholok, and Yantarnyi). The dominant iridoid was loganic acid, which constituted from $87 \%$ to $96 \%$ of all iridoids. In C. officinalis, the iridoid profile was different than in C. mas. In the former, morroniside was also identified, and it constituted the largest amount (67-72\% of all iridoids), while loganic acid was present in the smallest quantities (5-6\% of all iridoids). Other authors $[65,66]$ also confirmed the dominant participation of morroniside in the total amount of iridoids in Fructus Corni. However, Wang et al. [66] determined comparable amounts of morroniside and loganin in crude and processed Fructus Corni samples. The iridoid profile in hybrids was more similar to the profile of iridoids in C. mas fruit than to that in C. officinalis fruit. 
The dominant share of loganic acid in $\mathrm{CmCo}-01$ and $\mathrm{CmCo}-02$, respectively, $77 \%$ and $82 \%$ of the total amount of iridoids, indicates high similarity to $C$ mas. The similarity of the hybrid to $C$. officinalis was indicated by the presence of morroniside in $\mathrm{CmCo}-01$ and higher share of $\mathrm{S}+\mathrm{L}$ in $\mathrm{CmCo}-01(11 \%)$ and in $\mathrm{CmCo}-02(12 \%)$. However, this similarity is much lower than similarity to C. mas.

In previous studies, it was shown that the anthocyanin content of C. mas fruit is within a wide range and depends mainly on the cultivar [5]. In this study, similar dependence has been found. Among cultivars of $C$. mas, low levels of anthocyanins were found in Koralovyi (4.06 mg/100 g FW) and Koralovyi Marka (33.05 mg/100 g FW), whereas Ekzotychnyi contained high amounts of colorants $(74.50 \mathrm{mg} / 100 \mathrm{~g} \mathrm{FW}$, which is the typical concentration for red fruits). Black fruit of the Uholok cultivar was characterized by very high contents of anthocyanins ( $427.75 \mathrm{mg} / 100 \mathrm{~g} \mathrm{FW})$, and it is in this respect similar to the C27 genotype from East Azerbaijan province [27], the Czarny ecotype [5], and the Vermio cultivar-a Greek native cornelian cherry population [4]. The anthocyanin contents of Co-02 and Co-01 samples were similar at 10.52 and $17.18 \mathrm{mg} / 100 \mathrm{~g} \mathrm{FW}$, respectively. The average anthocyanin content of $C$. officinalis was over 3 times higher than the amount of anthocyanins in cv. Koralovyi, but over 2 times lower than in cv. Koralovyi Marka, over 5 times lower than in cv. Ekzotychnyi and almost 31 times lower than in cv Uholok. Vareed et al. [67] report more than 3 times lower total anthocyanin content in C. officinalis than in C. mas. For the two hybrids of C. mas $\times$ C. officinalis, the total content of anthocyanins ranged from $35.55 \mathrm{mg} / 100 \mathrm{~g}$ FW (CmCo-02) to $84.64 \mathrm{mg} / 100 \mathrm{~g}$ FW (CmCo-01). In our research, hybrids contained comparable amounts of anthocyanins as some cultivars of C. mas fruit and much higher than genotypes of $C$. officinalis fruit. This is the first report to determine the anthocyanin content of $C$. mas $\times$ C. officinalis fruit.

Five anthocyanins (delphinidin 3-O-galactoside, cyanidin 3-O-galactoside, cyanidin 3-O-robinobioside, pelargonidin 3-O-galactoside, and pelargonidin 3-O-robinobioside) were identified in most of the fruits studied. This is consistent with our previous report [5]. Among cultivars of C. mas, cyanidin derivatives dominated in Ekzotychnyi and Uholok fruit (redder in color), whereas pelargonidin derivatives dominated in Koralovyi Marka and Koralovyi fruits (more orange in color). In both C. officinalis and C. mas $\times$ C. officinalis, pelargonidin derivatives dominated, so the fruits were more orange than red.

The total flavonols content in C. mas, C. officinalis, and C. mas $\times$ C. officinalis fruit ranged from 0.47 (Koralovyi) to $10.67 \mathrm{mg} / 100 \mathrm{~g} \mathrm{FW}$ (Uholok), from 8.13 (Co-02) to $12.57 \mathrm{mg} / 100 \mathrm{~g}$ FW (Co-01), and from 0.81 (CmCo-02) to $3.62 \mathrm{mg} / 100 \mathrm{~g}$ FW (CmCo$01)$, respectively. On average, hybrids contained similar amounts of flavonols as in C. mas and much lower than that in C. officinalis. This is the first report to determine the flavonol content of C. mas $\times$ C. officinalis fruit.

Quercetin 3-O-glucuronide and kaempferol 3-O-galactoside were determined in C. mas, C. officinalis, and C. mas $\times$ C. officinalis fruit in various proportions. The exception was the yellow fruit of the Jantarnyj cultivar, because in this sample, a derivative of kaempferol was not found. Among C. mas, yellow and black fruits contained significantly more quercetin 3-O-glucuronide than pink and red fruits. In the Uholok cultivar, there was almost 5 times more kaempferol 3-O-galactoside than quercetin 3-O-glucuronide, while in the $\mathrm{Co}-01$ and $\mathrm{CmCo}-01$ samples, there was more quercetin 3-O-glucuronide than kaempferol 3-O-galactoside, 6 times more and almost 2 times, respectively.

\subsection{Antioxidant Capacity $(A C)$ of Cornus Fruit Extracts}

The antioxidant effect cannot be adequately tested using only one method, since plant extracts are multicomponent matrices with antioxidant capacity determined by the set of different reaction mechanisms $[68,69]$. Antioxidants are divided traditionally into primary and secondary ones. ABTS, DPPH, and FRAP tests provide information about direct action antioxidant (primary antioxidant). According to the mechanism of action, antioxidant tests are classified as HAT (hydrogen atom transfer) or SET (single electron transfer). In both reactions, the radical removes a hydrogen atom (HAT) or a single electron (SET) from 
the antioxidant and in consequence, the antioxidant becomes a radical. Distinguishing between HAT and SET mechanisms is difficult. As stated by Shalaby et al. [70], ABTS acts in HAT mode while FRAP, DPPH, and Folin-Ciocalteu tests are in SET mode, but according to Sun et al. [71], the Folin-Ciocalteu test and FRAP assay are based on the SET mechanism and ABTS and DPPH action is in mixed HAT/SET mode. In most cases, these two reactions occur simultaneously, and the reaction mechanism depends on the structure and solubility of the antioxidant, partition coefficient, and solvent polarity [71]. Therefore, for a more complete characterization of plant extracts that contain different substances, several different tests are most often performed during research [72].

In order to thoroughly evaluate the antioxidant capacity of the ethanol extracts of fruits of the studied genotypes, different antioxidant capacity assays (DPPH, ABTS, and FRAP) were employed.

The DPPH radical scavenging capacity of each Cornus mas (6.75-77.35 $\mu \mathrm{mol}$ TE/g), C. officinalis (17.82-39.79 $\mu \mathrm{mol} \mathrm{TE} / \mathrm{g})$, and C. mas $\times$ C. officinalis (20.81-45.57 $\mu \mathrm{mol} \mathrm{TE} / \mathrm{g})$ extract is shown in Figure 4.

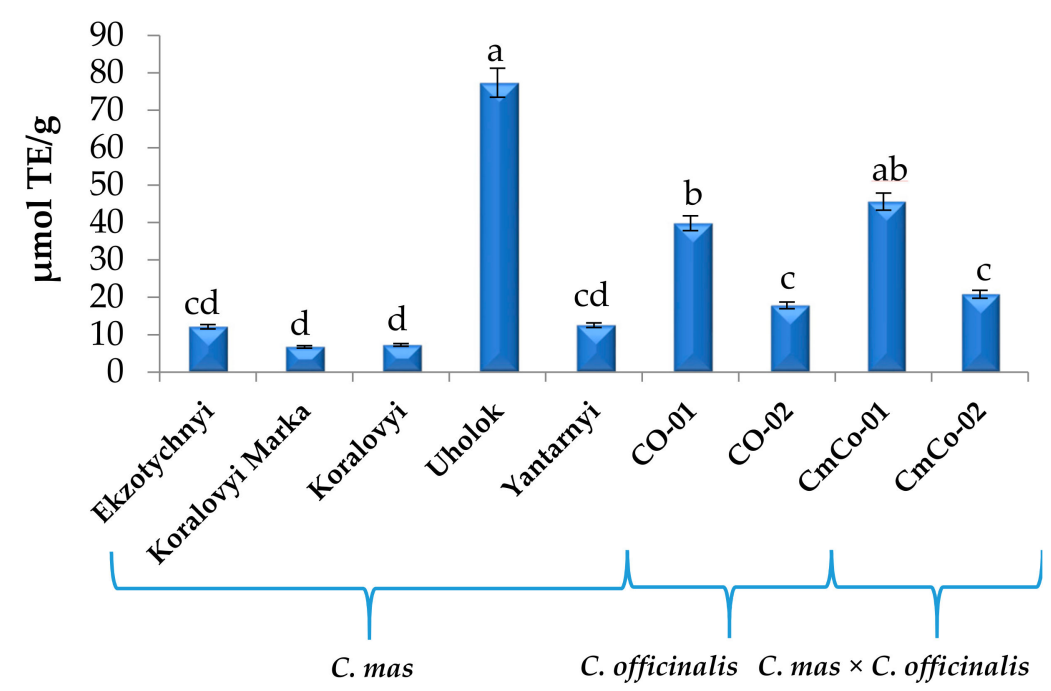

Figure 4. Antioxidant capacity of Cornus mas L., C. officinalis Siebold \& Zucc., and C. mas $\times$ C. officinalis fruits extracts evaluated by DPPH method, $\mu \mathrm{mol} \mathrm{TE} / \mathrm{g}$ (means in columns followed by different letters are statistically different at $p \leq 0.05$ ). DPPH, 2,2-diphenyl-1-picrylhydrazyl; TE, Trolox equivalent.

High antioxidant capacity of cv. Uholok $(77.35 \mu \mathrm{mol} \mathrm{TE} / \mathrm{g})$ is evidently caused by a high content of anthocyanins in the fruits (fruits of this cultivar stand out by a very intense, almost black color). At the same time, other rose fruits of Koralovyi Marka and Koralovyi cultivars contained much less anthocyanins compared with cv. Uholok. That is probably why the $\mathrm{AC}$ of fruit extracts of these cultivars was the lowest, even lower than $\mathrm{AC}$ of extract from the yellow fruit cultivar Yantarnyi. Higher activity of yellow fruit extract than rose fruit extracts may be due to the higher content of non-red active compounds. As shown in the data in Table 1, the yellow fruits contained about 4 times more quercetin 3-O-glucuronide than the rose fruits. Antioxidant capacity of $C$. officinalis genotypes ranged from 17.82 to $39.79 \mu \mathrm{mol} \mathrm{TE} / \mathrm{g}$. It was higher than the capacity of yellow, rose, and red fruit cultivars of Cornus mas but lower than that of the black fruit cultivar Uholok. Antioxidant capacity of C. mas $\times$ C. officinalis was also high $(20.81-45.57 \mu \mathrm{mol} \mathrm{TE} / \mathrm{g})$ compared with yellow, rose, and red fruit cultivars of $C$. mas because of good parent features of Lukianivsky and Olena cultivars (red fruits) from C. mas used in hybridization.

Many authors have studied the antioxidant capacity of $C$. mas fruit extracts. DragovicUzelac et al. [73] determined that DPPH values in two different Cornus mas types were between 33.41 and $39.89 \mathrm{mmol} \mathrm{TE} / \mathrm{kg}$ FW. Hassanpour et al. [27] stated that the efficiency of DPPH radicals' scavenging depended on the total polyphenolic concentration, total flavonoids, and ascorbic acid content. In the cited study, Iranian genotypes' fruit 
extracts scavenged DPPH radicals at levels varying from $38.98 \%$ to $77.6 \%$. According to Kucharska et al. [3], antioxidant capacity in Polish breeding cultivars was the highest in the Dublany cultivar $(20.72 \mu \mathrm{mol} \mathrm{TE} / \mathrm{g})$ and the lowest in the Juliusz cultivar $(10.85 \mu \mathrm{mol} \mathrm{TE} / \mathrm{g})$. Fewer authors have studied the antioxidant capacity by the DPPH method of C. officinalis fruit extracts or products $[9,74]$. The $\mathrm{IC}_{50}$ values for DPPH radical scavenging activities of C. officinalis dry extracts were $99.32 \mu \mathrm{g} / \mathrm{mL}$ [74] and $154 \mu \mathrm{g} / \mathrm{mL}$ [75]. According to Lim et al. [76], the DPPH-free radical scavenging capacity of dried C. officinalis fruit extract $(1 \mathrm{mg} / \mathrm{mL})$ was stronger than that of vitamin $\mathrm{E}$ at the same concentration. West et al. [9] observed that the ability of scavenging DPPH radicals was slightly higher in the case of C. officinalis juice, despite the lower concentration than in C. mas puree.

Another stable free radical cation, ABTS, was used to evaluate the antioxidant capacity of the cornelian cherry extracts (Figure 5).

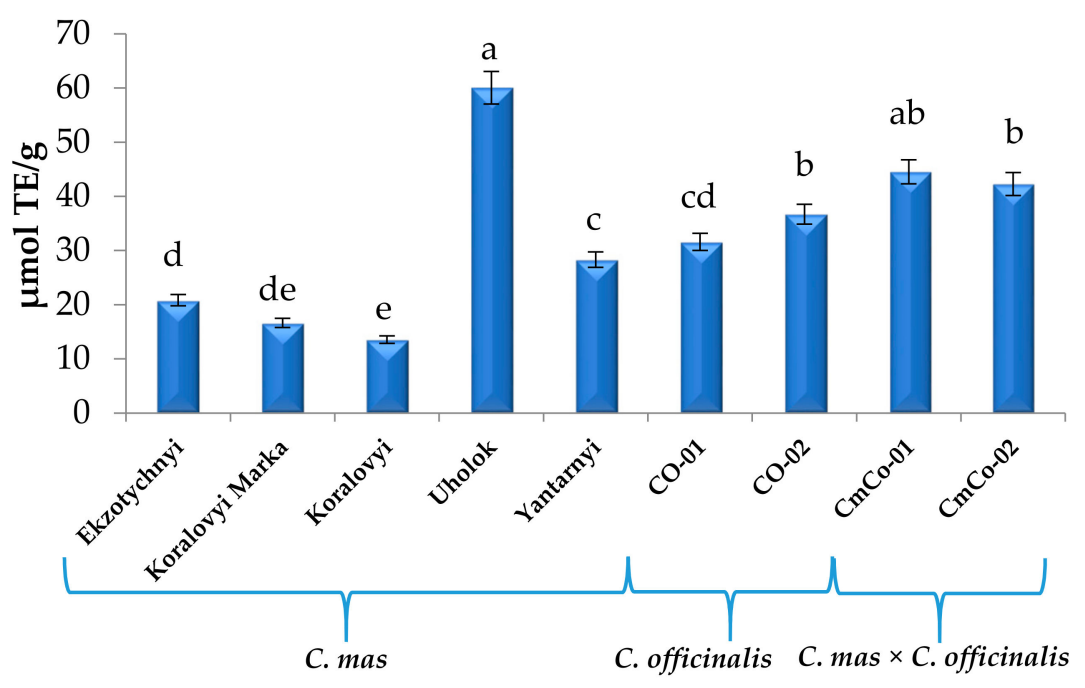

Figure 5. Antioxidant capacity of Cornus mas L., C. officinalis Siebold \& Zucc., and C. mas $\times$ C. officinalis fruit extracts evaluated by ABTS method, $\mu \mathrm{mol}$ TE $/ \mathrm{g}$ (means in columns followed by different letters are statistically different at $p \leq 0.05$ ). ABTS, 2,2'-azino-bis (3-ethyl benzothiazoline-6-sulfonic acid.

As shown in Figure 5, antioxidant capacity of extracts of Cornus mas cultivars measured by ABTS ranged from 13.56 (Koralovyi) to $60.04 \mu \mathrm{mol} \mathrm{TE} / \mathrm{g}$ (Uholok). Antioxidant capacity by ABTS shows the same tendency that was observed in the DPPH method and also was the highest for $\mathrm{cv}$. Uholok, higher in the genotypes of $C$. officinalis $(31.60-36.71 \mu \mathrm{mol} \mathrm{TE} / \mathrm{g})$ than cultivars C. mas, and high for C. mas $\times$ C. officinalis $(42.27-44.54 \mu \mathrm{mol} \mathrm{TE} / \mathrm{g})$, comparing all investigated genotypes (besides cv. Uholok).

Other authors obtained comparable or lower activities of C. mas fruits. Moldovan et al. [19] reported that the antioxidant capacity of fresh cornelian cherries was $677.88 \mu \mathrm{mol} \mathrm{TE} / 100$ g FW (ABTS assay). According to Rop et al. [77], the antioxidant capacity (ABTS assay) of fruits ranges from 3.65 (cv. Devin, Czech breeding) to $10.28 \mathrm{~g}$ of ascorbic acid equivalent per kilogram of fresh mass (AAE/kg FM) (cv. Vydubieckij, Russian breeding). According to Kucharska et al. [3], antioxidant capacity in Polish breeding cultivars of C. mas ranged from 18.87 (cv. Juliusz) to $38.96 \mu \mathrm{mol} \mathrm{TE} / \mathrm{g}$ (cv. Szafer). C. officinalis antioxidant activity was measured by Hwang et al. [74]. The authors reported that the $\mathrm{IC}_{50}$ values for ABTS radical scavenging activities of $C$. officinalis dried extracts were 138.51 and $154 \mu \mathrm{g} / \mathrm{mL}$.

By analyzing the antioxidant capacity results of genotypes of $C$. mas, C. officinalis, and C. mas $\times$ C. officinalis evaluated by the FRAP method (Figure 6), one can note the same tendency as that found for its determination by the two previous methods (Figures 4 and 5). Activity of hybrids C. mas $\times$ C. officinalis (35.01-35.33 $\mu \mathrm{mol} \mathrm{TE/g)} \mathrm{was}$ comparable to activity of $C$. officinalis (27.69-30.84 $\mu \mathrm{mol} \mathrm{TE} / \mathrm{g}$ ) but was higher than activity of typical C. mas (8.45-19.34 $\mu \mathrm{mol} \mathrm{TE} / \mathrm{g})$, except for Uholok $(76.12 \mu \mathrm{mol} \mathrm{TE} / \mathrm{g})$. 


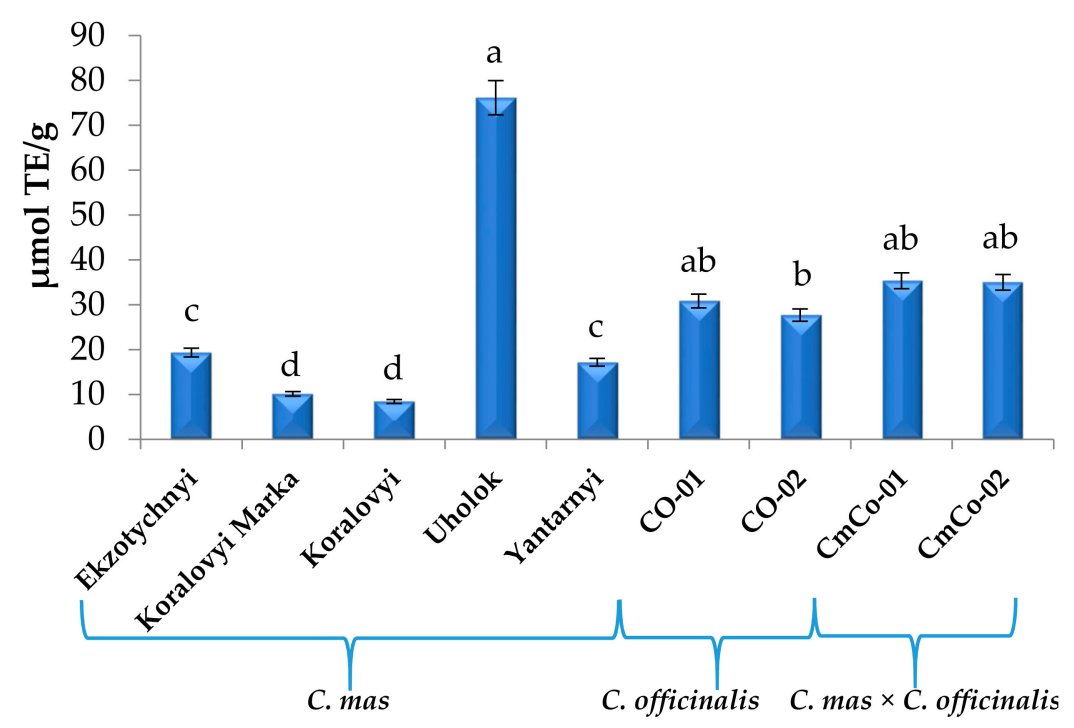

Figure 6. Antioxidant capacity of Cornus mas L., C. officinalis Siebold \& Zucc., and C. mas $\times$ C. officinalis fruits extracts evaluated by FRAP method, $\mu \mathrm{mol} \mathrm{TE} / \mathrm{g}$ (means in columns followed by different letters are statistically different at $p \leq 0.05$ ). FRAP, ferric reducing antioxidant power.

Many authors have studied the ferric reducing antioxidant power of C. mas, but unfortunately, not of $C$. officinalis. Depending on the cultivars of $C$. mas tested, they obtained FRAP values within wide limits. Reducing power of Polish cultivars of $C$. mas ranges from 21.17 (cv. Juliusz) to 41.08 (cv. Szafer) $\mu \mathrm{mol} \mathrm{TE/g} \mathrm{[3].} \mathrm{According} \mathrm{to} \mathrm{De} \mathrm{Biaggi} \mathrm{et} \mathrm{al.} \mathrm{[78],}$ the cornelian cherry extract can reduce $20.41 \mu \mathrm{mol} \mathrm{Fe}^{2+}$ per gram of solution. A study conducted by Yilmaz et al. [26] presented a significant range of FRAP values, in which the minimum and the maximum values were 73 and $114 \mu \mathrm{mol}$ of ascorbic acid equivalent per gram of dry weight (DW), respectively. Pantelidis et al. [4] confirmed that the FRAP value is approximately $84 \mu \mathrm{mol}$ AA/g DW. In Popović's research [13], the ferric reducing antioxidant power ranges from 2.1 to $5.8 \mu \mathrm{mol} / \mathrm{mL} \mathrm{Fe}^{2+}$.

\subsection{Total Phenolic Content (TPC) of the Cornus Fruit Extracts}

The results for TPC, determined by the Folin-Ciocalteu reagent for C. mas, varied in a wide range from 100.71 (Koralovyi) to $924.65 \mathrm{mg} \mathrm{GAE} / 100 \mathrm{~g}$ (Uholok), while for C. officinalis and hybrids $C$. mas $\times$ C. officinalis, the results were comparable and fell within the ranges of 318.57-451.04 and 410.20-554.01 mg/100 g, respectively (Figure 7).

The obtained results for $C$. mas were within the limits of the TPC values of $C$. mas published by several authors from Greece, the Czech Republic, Poland, Romania, Azerbaijan, and Turkey $[3,6,26,28,73]$. Rop et al. [77] stated that the total amount of polyphenols content was cultivar dependent. In their study, the total polyphenolic content was the lowest for cv. Devin of Czech breeding (261 mg GAE/100 g FW), while the highest concentration of polyphenol was for cv. Vydubieckii of Ukrainian breeding (811 mg GAE/100 g FW). The TPC of Cornus mas of Greek cultivars was $1592 \mathrm{mg}$ GAE; of Azerbaijani cultivars, 1097-2695 mg GAE; and of Turkish cultivars, 2659-7483 mg GAE [26,28]. According to Cetkovska et al. [28], TPC in Ukrainian breeding cultivars was the highest in the Ekzotychnyi cultivar (614.3 mg GAE/100 g DW) and the lowest in the Lukianivsky cultivar (182.3 mg GAE/100 g DW). According to Romanian researchers, the determined TPC of the fresh ripe fruits of cornelian cherry acquired from a local market from Cluj-Napoca was $489.94 \mathrm{mg}$ GAE/100 g FW [19]. Kucharska et al. [3] presented research cultivars of Polish breeding, among which the richest in polyphenols was cv. Szafer (464 mg/100 g) and the poorest was cv. Juliusz ( $262 \mathrm{mg} / 100 \mathrm{~g})$. Polyphenol content can be linked to fruit color $[79,80]$. The cultivar Szafer possessed the most intense purple color of all cultivars, and it was also the richest in TPC among the cultivars tested [3]. Milenkovic-Andjelkovic et al. [29] indicated in their study that the polyphenol content slightly depended on the 
cultivation conditions, which differ from year to year. TPC of $C$. officinalis was measured by Hwang et al. [74] and Jeon et al. [75]. According to these authors, the TPC of C. officinalis dry extracts, determined by the Folin-Ciocalteu reagent, was $27.04 \mathrm{mg}$ GAE/g and $34.22 \mathrm{mg} \mathrm{GAE} / \mathrm{g}$, respectively.

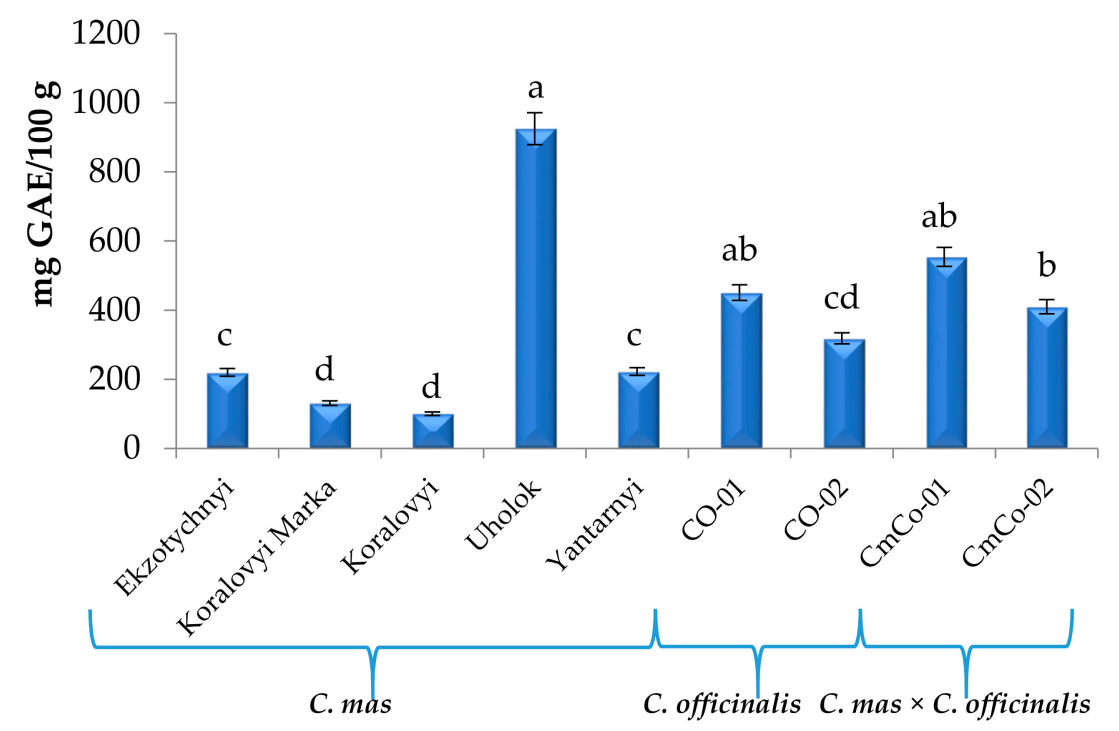

Figure 7. Total phenolic content (TPC) of C. mas L., C. officinalis Siebold \& Zucc., and C. mas $\times$ C. officinalis fruit extracts, $\mathrm{mg}$ GAE/100 $\mathrm{g}$ (means in columns followed by different letters are statistically different at $p \leq 0.05)$. GAE, gallic acid equivalent.

Correlation analysis was used to explore the relationships between the phenolic compounds, anthocyanins, flavonols, iridoids, and antioxidant capacities (ABTS, DPPH, and FRAP) measured for all fruit extracts from Cornus cultivars (Table 2).

Table 2. Correlation coefficients between antioxidant capacity and bioactive compounds.

\begin{tabular}{cccc}
\hline Components & DPPH & ABTS & FRAP \\
\hline Anthocyanins & $0.843^{*}$ & $0.716^{*}$ & $0.889^{*}$ \\
Iridoids & 0.234 & 0.129 & 0.106 \\
Flavonols & $0.707^{*}$ & 0.556 & 0.633 \\
TPC & $0.979^{*}$ & $0.942^{*}$ & $0.981^{*}$ \\
\hline
\end{tabular}

* Correlation is significant at the 0.05 level.

The findings of this study indicate that TPC present high and positive correlations with FRAP scavenging capacity, DPPH, and ABTS ( $r=0.981, r=0.979, r=0.942$, respectively). The correlation analysis between radical scavenging and phenolic composition has been additionally proven in many studies $[4,29,81]$.

Significant correlations were also found between the anthocyanins content and their ABTS radical scavenging $(r=0.716)$, DPPH radical scavenging $(r=0.843)$, and FRAP $(r=0.889)$ activities. The correlations between the flavonols content and antioxidant activities measured by ABTS $(r=0.556)$, DPPH $(r=0.707)$, and FRAP $(r=0.633)$ were slightly smaller than for anthocyanins and AC. Very weak correlations were observed between the iridoids content and the antioxidant activities measured by FRAP $(r=0.106)$, ABTS $(r=0.129)$, and DPPH $(r=0.234)$ assays (Table 2$)$. This is consistent with the earlier study of Kucharska et al. [82], where it was reported that iridoids did not exhibit a high correlation between their amount and in vitro antioxidant capacity (DPPH and FRAP) of blue honeysuckle berries. However, they exhibit a number of other beneficial biological activities [83] that can complement antioxidant capacity of phenolic compounds.

These findings indicated that the TPC, anthocyanins, and flavonols, but not iridoids, are the key determinants associated with the antioxidant activities of the extracts. 


\section{Conclusions}

The results of the present study showed that among the $C$. mas cultivars and C. officinalis genotypes, there was considerable variation in the content of iridoids and flavonoids and AC. Interspecific hybrids C. mas $\times$ C. officinalis contained more iridoids than C. mas and more anthocyanins than C. officinalis, and additionally, they had higher AC and TPC than C. officinalis and most C. mas. All fruit extracts of Cornus mas, C. officinalis, and C. mas $\times$ C. officinalis exhibited strong antioxidant activities, which correlated positively with the total phenolic content and phenolic compounds as anthocyanins and flavonols, but did not correlate with the iridoids content. In the C. mas cultivars, activity depended on the color of the fruit. The cultivar Uholok with almost black fruit had the highest antioxidant potential, while the pink fruit cultivars had the lowest. The AC of $C$. mas $\times$ C. officinalis new hybrids was higher than that of the AC of C. officinalis genotypes and C. mas cultivars, except for cv. Uholok. Genotypes of our selection differ in higher values of biochemical parameters in comparison with cultivars of other studies. Currently, this plant is less known and this new source can potentially be used as a functional food or value-added ingredient in the future in our dietary system. The results of our study suggest the great value of the fruits of Cornus mas, C. officinalis, and particularly of C. mas $\times$ C. officinalis for use in pharmacy and phytotherapy. Therefore, further studies should be conducted, with particular attention to validate these in vitro results in cellular or animal models.

Author Contributions: Conceptualization, S.K. and O.G.; methodology, S.K., A.Z.K., and A.S.-Ł.; investigation, S.K., O.G., A.Z.K., A.S.-Ł., and D.P.; resources, S.K., O.G., and N.P.; data curation, S.K., N.P., and A.Z.K.; writing—original draft preparation, S.K., O.G., and A.Z.K.; writing-review and editing, D.P.; visualization, S.K., O.G., and A.Z.K.; supervision, S.K., O.G., A.S.-Ł., and A.Z.K.; project administration, O.G.; funding acquisition, S.K., O.G., A.S.-Ł., and N.P. All authors have read and agreed to the published version of the manuscript.

Funding: This research received no external funding.

Acknowledgments: The publication was prepared with the active participation of researchers in the international network AgroBioNet, as a part of the International Program 'Agricultural Biodiversity to Improve Nutrition, Health and Quality of Life'. The authors are grateful to the Polish National Commission for UNESCO, Bilateral Scholarship of the Ministry of Education, Science, Research and Sport (Slovak Republic) and Visegrad Fund.

Conflicts of Interest: The authors declare no conflict of interest.

\section{References}

1. Brindza, P.; Brindza, J.; Tóth, D.; Klimenko, S.; Grigorieva, O. Biological and commercial characteristics of cornelian cherry (Cornus mas L.) Population in the Gemer Region of Slovakia. Acta Hortic. 2009, 818, 85-94. [CrossRef]

2. Klymenko, S.; Grygorieva, O.; Brindza, J. Less Known Species of fruIt Crops; Slovak University of Agriculture in Nitra: Nitra, Slovakia, 2017. [CrossRef]

3. Kucharska, A.Z.; Sokół-Łętowska, A.; Piórecki, N. Morphological, physical \& chemical, and antioxidant profiles of polish varieties of cornelian cherry fruit (Cornus mas L.). Żywn. Nauka Technol. Jakość 2011, 3, 78-89.

4. Pantelidis, G.E.; Vasilakakis, M.; Manganaris, G.A.; Diamantidis, G. Antioxidant capacity, phenol, anthocyanin and ascorbic acid contents in raspberries, blackberries, red currants, gooseberries and cornelian cherries. Food Chem. 2007, 102, 777-783. [CrossRef]

5. Kucharska, A.Z.; Szumny, A.; Sokół-Łętowska, A.; Piórecki, N.; Klymenko, S.V. Iridoids and anthocyanins in cornelian cherry (Cornus mas L.) cultivars. J. Food Compos. Anal. 2015, 40, 95-102. [CrossRef]

6. Tural, S.; Koca, I. Physico-chemical and antioxidant properties of cornelian cherry fruits (Cornus mas L.) grown in Turkey. Sci. Hortic. 2008, 116, 362-366. [CrossRef]

7. Jayaprakasam, B.; Olson, L.K.; Schutzki, R.E.; Tai, M.-H.; Nair, M.G. Amelioration of obesity and glucose intolerance in High-FatFed C57BL/6 Mice by anthocyanins and ursolic acid in cornelian cherry (Cornus mas). J. Agric. Food Chem. 2006, 54, 243-248. [CrossRef] [PubMed]

8. Deng, S.; West, B.J.; Jensen, C.J. UPLC-TOF-MS characterization and identification of bioactive iridoids in Cornus mas Fruit. J. Anal. Methods Chem. 2013, 2013, 1-7. [CrossRef]

9. West, B.J.; Deng, S.; Jensen, C.J.; Palu, A.K.; Berrio, L.F. Antioxidant, toxicity, and iridoid tests of processed cornelian cherry fruits. Int. J. Food Sci. Technol. 2012, 47, 1392-1397. [CrossRef] 
10. Bakirtzi, C.; Tsatalas, P.; Spanakis, M.; Kokkalou, E. GC-MS analysis of volatile constituents of Cornus mas fruits and pulp. J. Essent. Oil Bear. Plants 2013, 16, 183-200. [CrossRef]

11. Soltani, R.; Gorji, A.; Asgary, S.; Sarrafzadegan, N.; Siavash, M. Evaluation of the effects of Cornus mas L. fruit extract on glycemic control and insulin level in type 2 diabetic adult patients: A randomized double-blind placebo-controlled clinical trial. Evid.-Based Complement. Altern. Med. 2015, 2015, 1-5. [CrossRef]

12. Shishehbor, F.; Azemi, M.E.; Zameni, D.; Saki, A. Inhibitory effect of hydroalcoholic extracts of barberry, sour cherry and cornelian Cherry $\alpha$-amylase and $\alpha$-Glucosidase activities. Int. J. Pharm. Res. Allied Sci. 2016, 5, 423-428.

13. Popović, B.M.; Štajner, D.; Slavko, K.; Sandra, B. Antioxidant capacity of cornelian cherry (Cornus mas L.)-comparison between permanganate reducing antioxidant capacity and other antioxidant methods. Food Chem. 2012, 134, 734-741. [CrossRef]

14. Rafieian-Kopaei, M.; Asgary, S.; Adelnia, A.; Setorki, M.; Khazaei, M.; Kazemi, S. The effects of cornelian cherry on athero-sclerosis and atherogenic factors in hypercholesterolemic rabbits. J. Med. Plant Res. 2011, 5, 2670-2676.

15. Mehrabi, M.; Sadraie, J.; Ghaffarifar, F. Comparative study of the effect of garlic tablet and blueberry extract on Cryptosporidum parvumoocysts in HANK solution. Sci. J. Kurdistan Univ. Med Sci. 2012, 17, 53-60.

16. Darbandi, N.; Hashemi, A.; Noori, M.; Momeni, H.R. Effect of Cornus mas fruit flavonoids on memory retention, level of plasma glucose and lipids in an intracerebroventricular streptozotocin-induced experimental Alzheimer's disease model in Wistar rats. Environ. Exp. Biol. 2016, 14, 113-120. [CrossRef]

17. Rezaei, F.; Shokrzadeh, M.; Majd, A.; Nezhadsattari, T. Cytotoxic effect of hydroalcoholic extract of Cornus mas L. fruit on MCF7, HepG2 and CHO cell line by MTT Assay. J. Maz. Univ. Med. Sci. 2014, 24, 130-138.

18. Somi, M.H.; Banihabib, N.; Dehghan, G.; Haghi, M.E.; Panahi, F. Hepatoprotective effect of Cornus mas fruits extract against carbon tetrachloride-induced hepatic damage in male albino rats. Thrita 2014, 3, 17625. [CrossRef]

19. Moldovan, B.; Filip, A.; Clichici, S.; Suharoschi, R.; Bolfa, P.; David, L. Antioxidant activity of cornelian cherry (Cornus mas L.) fruits extract and the in vivo evaluation of its anti-inflammatory effects. J. Funct. Foods 2016, 26, 77-87. [CrossRef]

20. Bakirtzi, C.; Tsatalas, P.; Gabrieli, C.; Plioukas, M.; Kokkalou, E. LC-DAD-MS analysis, antioxidant and biological activities of Cornus mas fruits and pulp. J. Pharm. Biol. 2015, 5, 320-328.

21. Klimenko, S. The cornelian cherry (Cornus mas L.); collection, preservation and utilization of genetic resources. J. Fruit Ornam. Plant Res. 2004, 12, 93-98.

22. Brindza, P.; Brindza, J.; Tóth, D.; Klimenko, S.; Grigorieva, O. Slovakian cornelian cherry (Cornus mas L.): Potential for cultivation. Acta Hortic. 2007, 760, 433-437. [CrossRef]

23. Horváth, G.; Turcsi, E.; Molnár, P.; Szabó, L.G.; Deli, J. University of Pécs Institute of Pharmacognosy Pécs Rókus u. Hungary isolation and identification of carotenoids in the fruit of cornelian cherry (Cornus mas L.). Planta Med. 2007, 73, P_286. [CrossRef]

24. Leskovac, A.; Joksić, G.; Jankovic, T.; Šavikin, K.; Menković, N. Radioprotective properties of the phytochemically characterized extracts of Crataegus monogyna, Cornus mas and Gentianella austriaca on human lymphocytes in vitro. Planta Med. 2007, 73, 1169-1175. [CrossRef] [PubMed]

25. Kucarska, A.Z.; Szumny, A.; Sokół-Łętowska, A.; Zając, K. Fatty acid compositions of seed oils of cornelian cherry (Cornus mas L.). Acta Biochim. Pol. 2009, 56, 21-22.

26. Yilmaz, K.; Ercisli, S.; Zengin, Y.; Sengul, M.; Kafkas, E. Preliminary characterisation of cornelian cherry (Cornus mas L.) genotypes for their physico-chemical properties. Food Chem. 2009, 114, 408-412. [CrossRef]

27. Hassanpour, H.; Yousef, H.; Jafar, H.; Mohammad, A. Antioxidant capacity and phytochemical properties of cornelian cherry (Cornus mas L.) genotypes in Iran. Sci. Hortic. 2011, 129, 459-463. [CrossRef]

28. Cetkovská, J.; Diviš, P.; Vespalcová, M.; Pořízka, J.; Reznicek, V. Basic nutritional properties of cornelian cherry (Cornus mas L.) cultivars grown in the Czech Republic. Acta Aliment. 2015, 44, 357-364. [CrossRef]

29. Milenkovic-Andjelkovic, A.; Andjelkovic, M.; Radovanovic, A.; Radovanovic, B.; Nikolic, V. Phenol composition, DPPH radical scavenging and antimicrobial activity of cornelian cherry (Cornus mas) fruit and leaf extracts. Chem. Ind. 2015, 69, 331-337. [CrossRef]

30. Przybylska, D.; Kucharska, A.Z.; Cybulska, I.; Sozański, T.; Piórecki, N.; Fecka, I. Cornus mas L. stones: A valuable by-product as an ellagitannin source with high antioxidant potential. Molecules 2020, 25, 4646. [CrossRef]

31. Efenberger-Szmechtyk, M.; Nowak, A.; Czyżowska, A.; Kucharska, A.Z.; Fecka, I. Composition and antibacterial activity of Aronia melanocarpa (Michx.) Elliot, Cornus mas L. and Chaenomeles superba Lindl. leaf extracts. Molecules 2020, 25, 2011. [CrossRef]

32. Moussouni, S.; Karakousi, C.V.; Tsatalas, P.; Lazari, D.; Kokkalou, E. Biological studies with phytochemical analysis of Cornus mas unripe fruits. Chem. Nat. Compd. 2020, 56, 141-144. [CrossRef]

33. Ma, W.; Wang, K.-J.; Cheng, C.-S.; Yan, G.-Q.; Lu, W.-L.; Ge, J.-F.; Cheng, Y.-X.; Li, N. Bioactive compounds from Cornus officinalis fruits and their effects on diabetic nephropathy. J. Ethnopharmacol. 2014, 153, 840-845. [CrossRef] [PubMed]

34. Huang, J.; Zhang, Y.; Dong, L.; Gao, Q.; Yin, L.; Quan, H.; Chen, R.; Fu, X.; Lin, D. Ethnopharmacology, phytochemistry, and pharmacology of Cornus officinalis Sieb. et Zucc. J. Ethnopharmacol. 2018, 213, 280-301. [CrossRef]

35. Ding, X.; Wang, M.-Y.; Yu, Z.-L.; Hu, W.; Cai, B.-C. Studies on separation, appraisal and the biological activity of 5-HMF in Cornus officinalis. China J. Chin. Mater. Med. 2008, 33, 392-396.

36. Koo, B.-S.; Kim, Y.-K.; Park, K.-S.; Chung, K.-H.; Kim, C.-H. Attenuating effect of a traditional korean formulation, Paeng-Jo-YeonNyeon-Baek-Ja-In-Hwan(PJBH), on hydrogen peroxide-induced injury in PC12 cells. Phytother. Res. 2004, 18, 488-493. [CrossRef] [PubMed] 
37. Lee, W.-C.; Wu, C.-C.; Chuang, Y.-C.; Tain, Y.-L.; Chiang, P.-H. Ba-Wei-Die-Huang-Wan (Hachimi-jio-gan) can ameliorate cyclophosphamide-induced ongoing bladder overactivity and acidic adenosine triphosphate solution-induced hyperactivity on rats prestimulated bladder. J. Ethnopharmacol. 2016, 184, 1-9. [CrossRef]

38. Cao, G.; Zhang, Y.; Cong, X.D.; Cai, H.; Cai, B.C. Research progress on the chemical constituents and pharmacological activities of Fructus Corni. J. Chin. Pharm. Sci. 2009, 18, 208.

39. Lee, N.-H.; Seo, C.-S.; Lee, H.-Y.; Jung, D.-Y.; Lee, J.-K.; Lee, J.-A.; Song, K.Y.; Shin, H.-K.; Lee, M.-Y.; Seo, Y.B.; et al. Hepatoprotective and antioxidative activities of Cornus officinalis against acetaminophen-induced hepatotoxicity in mice. Evid. Based Complement. Altern. Med. 2011, 2012, 1-8. [CrossRef]

40. Bai, C.; Cao, B.; Li, G.; Mao, M. Ecological effects on phenotypic, cytological and biochemical diversity of Cornus officinalis germplasm resources in China and USA. Biochem. Syst. Ecol. 2014, 55, 241-248. [CrossRef]

41. Jeong, E.J.; Kim, T.B.; Yang, H.; Kang, S.Y.; Kim, S.Y.; Sung, S.H.; Kim, Y.C. Neuroprotective iridoid glycosides from Cornus officinalis fruits against glutamate-induced toxicity in HT22 hippocampal cells. Phytomedicine 2012, 19, 317-321. [CrossRef] [PubMed]

42. Quah, Y.; Lee, S.-J.; Lee, E.-B.; Birhanu, B.; Ali, S.; Abbas, M.; Boby, N.; Im, Z.-E.; Park, S.-C. Cornus officinalis ethanolic extract with potential anti-allergic, anti-inflammatory, and antioxidant activities. Nutrients 2020, 12, 3317. [CrossRef] [PubMed]

43. Wang, W.; Sun, F.; An, Y.; Ai, H.; Zhang, L.; Huang, W.; Li, L. Morroniside protects human neuroblastoma SH-SY5Y cells against hydrogen peroxide-induced cytotoxicity. Eur. J. Pharmacol. 2009, 613, 19-23. [CrossRef] [PubMed]

44. Liu, P.; Yang, P.; Zhang, L. Mode of action of Shan-Zhu-Yu (Cornus officinalis Sieb. et Zucc.) in the treatment of depression based on network pharmacology. Evid. Based Complement. Altern. Med. 2020, 2020, 1-10. [CrossRef]

45. Kwon, S.-H.; Park, H.-Y.; Kim, J.-Y.; Jeong, I.-Y.; Lee, M.-K.; Seo, K.-I. Apoptotic action of ursolic acid isolated from Corni fructus in RC-58T/h/SA\#4 primary human prostate cancer cells. Bioorganic Med. Chem. Lett. 2010, 20, 6435-6438. [CrossRef]

46. Zhang, Y.E.; Liu, E.H.; Hui-Jun, L.I.; Ping, L.I. Chemical constituents from the fruit of Cornus officinalis. Chin. J. Nat. Med. 2010, 7, 365-367. [CrossRef]

47. Xie, X.-Y.; Wang, R.; Shi, Y.-P. Chemical constituents from the fruits of Cornus officinalis. Biochem. Syst. Ecol. 2012, 45, 120-123. [CrossRef]

48. He, J.; Ye, X.-S.; Wang, X.-X.; Yang, Y.-N.; Zhang, P.-C.; Ma, B.-Z.; Zhang, W.-K.; Xu, J.-K. Four new iridoid glucosides containing the furan ring from the fruit of Cornus officinalis. Fitoterapia 2017, 120, 136-141. [CrossRef] [PubMed]

49. Dong, Y.; Feng, Z.-L.; Chen, H.-B.; Wang, F.-S.; Lu, J.-H. Corni Fructus: A review of chemical constituents and pharmacological activities. Chin. Med. 2018, 13, 1-20. [CrossRef]

50. Tian, W.; Zhao, J.; Lee, J.-H.; Akanda, R.; Cho, J.-H.; Kim, S.-K.; Choi, Y.-J.; Park, B.-Y. Neuroprotective effects of Cornus officinalis on stress-induced hippocampal deficits in rats and H2O2-induced neurotoxicity in SH-SY5Y neuroblastoma cells. Antioxidants 2019, 9, 27. [CrossRef] [PubMed]

51. Lee, S.H.; Tanaka, T.; Nonaka, G.-I.; Nishioka, I. Sedoheptulose digallate from Cornus officinalis. Phytochemistry 1989, 28 , 3469-3472. [CrossRef]

52. Li, Y.-C.; Yang, J.; Wu, X.-G.; Xu, X.-J.; Fu, Q.-Y. Three new iridoids from leaves of Cornus officinalis. J. Asian Nat. Prod. Res. 2015, 17, 788-792. [CrossRef]

53. Analysis of nutritional components of Cornus officianalis. J. Korean Soc. Food Sci. Nutr. 2003, 32, 785-789. [CrossRef]

54. Bai, C.; Li, P.; Wang, Z. Analysis of fat-soluble components in Cornus officinalis flesh and seeds by GC-MS. Food Sci. 2007, 28, 493-496.

55. Lee, J.; Jang, D.S.; Kim, N.H.; Lee, Y.M.; Kim, J.; Kim, J.S. Galloyl glucoses from the seeds of Cornus officinalis with inhibitory activity against protein glycation, aldose reductase, and cataractogenesis ex vivo. Biol. Pharm. Bull. 2011, 34, 443-446. [CrossRef]

56. Li, Y.-C.; Yang, J.; Li, J.-K.; Liang, X.-H.; Sun, J.-L. Two new secoiridoid glucosides from the twigs of Cornus officinalis. Chem. Nat. Compd. 2016, 52, 647-650. [CrossRef]

57. Morozowska, M.; Gawrońska, B.; Woźnicka, A. Morphological, anatomical and genetic differentiation of Cornus mas, Cornus officinalis and their interspecific hybrid. Dendrobiology 2013, 70, 45-57. [CrossRef]

58. Klymenko, S.; Ilyinska, A. Biometric characteristics of fruits and leaves of Cornus officinalis Siebold et Zucc. genotypes in the M.M. Gryshko National Botanical Garden of the NAS of Ukraine. Plant Introd. 2020, 85-86, 25-40. [CrossRef]

59. Gao, X.; Ohlander, M.; Jeppsson, N.; Björk, L.; Trajkovski, V. Changes in antioxidant effects and their relationship to phytonutrients in fruits of sea buckthorn (Hippophae rhamnoides L.) during maturation. J. Agric. Food Chem. 2000, 48, 1485-1490. [CrossRef]

60. Yen, G.-C.; Chen, H.-Y. Antioxidant activity of various tea extracts in relation to their antimutagenicity. J. Agric. Food Chem. 1995, 43, 27-32. [CrossRef]

61. Re, R.; Pellegrini, N.; Proteggente, A.; Pannala, A.; Yang, M.; Rice-Evans, C. Antioxidant activity applying an improved ABTS radical cation decolorization assay. Free Radic. Biol. Med. 1999, 26, 1231-1237. [CrossRef]

62. Klymenko, S.; Kucharska, A.Z.; Sokół-Łętowska, A.; Piórecki, N. Antioxidant activities and phenolic compounds in fruits of cultivars of cornelian cherry (Cornus mas L.). Agrobiodiversity Improv. Nutr. Health Life Qual. 2019, 3, 484-499. [CrossRef]

63. Du, W.; Cai, H.; Wang, M.; Ding, X.; Yang, H.; Cai, B. Simultaneous determination of six active components in crude and processed Fructus Corni by high performance liquid chromatography. J. Pharm. Biomed. Anal. 2008, 48, 194-197. [CrossRef] [PubMed] 
64. Liu, Y.; Liu, H.; Zhang, J. Total saponins of Cornus officinalis Sieb. ameliorates the endothelium dependent relaxation of mesenteric artery by regulating nitric oxide release in streptozotocin-induced diabetic rats. Zhong Nan Da Xue Xue Bao Yi Xue Ban 2012, 37, 757-764.

65. Liu, Z.; Zhu, Z.; Zhang, H.; Tan, G.; Chen, X.; Chai, Y. Qualitative and quantitative analysis of Fructus Corni using ultrasound assisted microwave extraction and high performance liquid chromatography coupled with diode array UV detection and time-of-flight mass spectrometry. J. Pharm. Biomed. Anal. 2011, 55, 557-562. [CrossRef]

66. Wang, L.; Chen, H.; Jiang, Y.; Liu, Z.; Wang, Q.; Zheng, X. Simultaneous Determination of 11 high-polarity components from Fructus Corni: A quantitative LC-MS/MS method for improved quality control. J. Chromatogr. Sci. 2017, 56, 56-64. [CrossRef]

67. Vareed, S.K.; Reddy, M.K.; Schutzki, R.E.; Nair, M.G. Anthocyanins in Cornus alternifolia, Cornus controversa, Cornus kousa and Cornus florida fruits with health benefits. Life Sci. 2006, 78, 777-784. [CrossRef]

68. Prior, R.L.; Wu, X.; Schaich, K. Standardized Methods for the determination of antioxidant capacity and phenolics in foods and dietary supplements. J. Agric. Food Chem. 2005, 53, 4290-4302. [CrossRef] [PubMed]

69. Li, W.; Hydamaka, A.W.; Lowry, L.; Beta, T. Comparison of antioxidant capacity and phenolic compounds of berries, chokecherry and seabuckthorn. Open Life Sci. 2009, 4, 499-506. [CrossRef]

70. Shalaby, A.; Shanab, S.M.M. Antioxidant compounds, assays of determination and mode of action. Afr. J. Pharm. Pharmacol. 2013, 7, 528-539. [CrossRef]

71. Sun, Y.; Yang, C.; Tsao, R. Nomenclature and general classification of antioxidant activity/capacity assays. In Measurement of Antioxidant Activity \& Capacity; Apak, R., Capanoglu, E., Shahidi, F., Eds.; John Wiley \& Sons Ltd.: Hoboken, NJ, USA, 2017. [CrossRef]

72. Dorta, E.; Fuentes-Lemus, E.; Speisky, H.; Lissi, E.; López-Alarcón, C. Evaluation of the antioxidant capacity of food samples: A chemical examination of the oxygen radical absorbance capacity assay. In Measurement of Antioxidant Activity E Capacity; Apak, R., Capanoglu, E., Shahidi, F., Eds.; John Wiley \& Sons Ltd.: Hoboken, NJ, USA, 2017; pp. 39-55. [CrossRef]

73. Dragovic-Uzelac, V.; Levaj, B.; Bursa, D.; Pedisi, S.; Radoji, I.; Biško, A. Total phenolics and antioxidant capacity assays of selected fruits. Agric. Conspec. Sci. 2007, 72, 279-284.

74. Hwang, K.-A.; Hwang, Y.-J.; Song, J. Antioxidant activities and oxidative stress inhibitory effects of ethanol extracts from Cornus officinalis on raw 264.7 cells. BMC Complement. Altern. Med. 2016, 16, 1-9. [CrossRef] [PubMed]

75. Jeon, Y.-H.; Kim, M.-H.; Kim, M.-R. Antioxidative, Antimutagenic, and Cytotoxic Activities of Ethanol Extracts from Cornus officianalis. J. Korean Soc. Food Sci. Nutr. 2008, 37, 1-7. [CrossRef]

76. Lim, S.-H.; Choi, S.H.; Oh, Y.I.; Kim, S.-J. Anti-oxidative effects of flavonoids enriched Corni fructus extract and the mechanism. Afr. J. Pharm. Pharmacol. 2011, 5, 506-514. [CrossRef]

77. Rop, O.; Mlcek, J.; Kramarova, D.; Jurikova, T. Selected cultivars of cornelian cherry (Cornus mas L.) as a new food source for human nutrition. Afr. J. Biotechnol. 2010, 9, 1205-1210. [CrossRef]

78. De Biaggi, M.; Donno, D.; Mellano, M.G.; Riondato, I.; Rakotoniaina, E.N.; Beccaro, G.L. Cornus mas (L.) fruit as a potential source of natural health-promoting compounds: Physico-chemical characterisation of bioactive components. Plant Foods Hum. Nutr. 2018, 73, 89-94. [CrossRef]

79. Demir, F.; Kalyoncu, I.H. Some nutritional, pomological and physical properties of cornelian cherry (Cornus mas L.). J. Food Eng. 2003, 60, 335-341. [CrossRef]

80. Bijelić, S.M.; Gološin, B.R.; Todorović, J.I.N.; Cerović, S.B.; Popović, B.M. Physicochemical fruit characteristics of cornelian cherry (Cornus mas L.) Genotypes from Serbia. HortScience 2011, 46, 849-853. [CrossRef]

81. Ersoy, N.; Bagci, Y.; Gok, V. Antioxidant properties of 12 cornelian cherry fruit types (Cornus mas L.) selected from Turkey. Sci. Res. Essays 2011, 6, 98-102. [CrossRef]

82. Kucharska, A.Z.; Sokół-Łętowska, A.; Oszmiański, J.; Piórecki, N.; Fecka, I. Iridoids, phenolic compounds and antioxidant activity of edible honeysuckle berries (Lonicera caerulea var. kamtschatica Sevast.). Molecules 2017, 22, 405. [CrossRef] [PubMed]

83. Ghisalberti, E. Biological and pharmacological activity of naturally occurring iridoids and secoiridoids. Phytomedicine 1998, 5, 147-163. [CrossRef] 